UDC 94 (477) (092)

DOI: $10.24919 / 2519-058 x .7 .130671$

Vitalii TELVAK,

orcid.org/0000-0002-2445-968X

Ph D hab. (History), Professor at Department of World History and Special Historical Disciplines, Ivan Franko Drohobych State Pedagogical University (Drohobych, Ukraine)

telvak1@yahoo.com

Viktoria TELVAK, orcid.org/0000-0003-4671-743X

Ph D hab. (History), Assistant Professor, Department of World History and Special Historical Disciplines, Ivan Franko Drohobych State Pedagogical University

(Drohobych,Ukraine) vitalitelvak@gmail.com

\title{
UKRAINIAN HISTORIOGRAPHY IN THE MIRROR \\ OF POLISH JOURNALISM (MYKHAILO HRUSHEVSKYI CONTRA FRANCISHEK RAVITA-GAVRONSKY)
}

This article is devoted to the analisys of the views of the Polish journalist F. Ravita-Havronsky on Hrushevskyi's socio-political and scientific activity. The pacularities of the relationship of the Polish journalist with the historical ideology and historiographical practice of the Ukrainian scientist has been reconstructed. The conclusion about the influence of F. Ravita-Havronske's interpretations among the Polish intelligentsia of the end of XIX th - the first third of the XX th century has been made.

Key words: F. Ravita-Havronsky, Hrushevskyii studies, journalism, History of Ukraine-Rus.

Віталій ТЕЛЬВАК, доктор історичних наук, професор кафедри всесвітньої історії та спеиіальних історичних дисииплін Дрогобицького держсавного педагогічного університету (Україна, Дрогобич) telvak1@yahoo.com

Вікторія ТЕЛЬВАК, кандидат історичних наук, доиент кафедри всесвітньої історії та спеиіальних історичних дисииплін Дрогобищького державного педагогічного університету

(Україна, Дрогобич) vitalitelvak@gmail.com

\section{УКРАЇНСЬКА ІСТОРІОГРАФІЯ У ДЗЕРКАЛІ ПОЛЬСЬКОӤ ПУБЛЦЦИТИКИ (МИХАЙЛО ГРУШЕВСЬКИЙ СОNТRА ФРАНЦІШЕК РАВІТА-ГАВРОНСЬКИЙ)}

Стаття присвячена аналізу поглядів польського публічиста Ф. Равіти-Гавронського на суспільно-політичну та наукову діяльність М. Грушевського. Відтворено особливості ставлення польського публічиста до історичної ідеології та історіографічної практики украӥнського вченого. Зроблено висновок про впливовість інтерпретачій Ф. Равіти-Гавронського в середовиші польської інтелігенції кіния XIX - першої третини XX сm.

Ключові слова: Ф. Равіта-Гавронський, грушевськіана, публіцистика, «Історія України-Руси».

The problem statement. The Polish Hrushevskyii studies began at the end of the nineteenth century, when the youngest student of the Kiev documentary school Volodymyr Antonovych at that time published his first scientific research. During the subsequent decades, 
until the death of the scientist in 1934, the assessment of the work of M. Hrushevskyii by Polish colleagues depended both on the intensity of his scientific work and on the general state of interethnic relations in which the author of the «History of Ukraine-Rus» often played a prominent, and sometimes, a determining role. Noting the periods of intensification and weakening of Hrushevskyi studies reflection in the intellectual culture of our neighbors, we emphasize that the attitude of Polish figures to the leader of Ukrainian historiography was always emotional, including not only understanding of the importance of his contribution to the scientific understanding of historical processes in the East European historiographical space, but also the public resonance and the influence of the proposed hypotheses.

In view of this, in the Polish Hrushevskyi studies we can distinguish between two connected nuclei - historiographical and journalistic one. The representatives of the first emphasized on the science-education component of the broad-based academic activity of Ukrainian colleagues, arguing with them on numerous professional problems. Representatives of the other, the Polish political writers, accentuated the ideological component of the historical activity of M. Hrushevskyi and the influence of his historiographical hypotheses on contemporary Ukrainian society. It should be noted that due to the peculiarities of communication with the reader (first and foremost through periodicals and popular science publications), their influence on the broad circles of Polish society was larger, and they themselves shaped the image of M. Hrushevskyi in the mass consciousness.

One of the most striking Polish publicists and popularizers of historical knowledge in the second half of the nineteenth - first third of the twentieth century was an agronomist Francishek Ravita-Gavronsky (1846 - 1930). Advocating the idea of the expediency of Poland's rebirth within the territorial limits of the First Commonwealth, he certainly encountered representatives of the growing Ukrainian intellectual movement, which emphasized the right of Ukrainians not only for cultural but also for political self-determination within their own ethnic lands. Hence, the historical ideas of the leader of the Ukrainian life, M. Hrushevskyi, were fully in the focus of the critical attention of the Polish publicist. Despite the fact that the Ukrainian studies works of F. Ravita-Gavronsky have been repeatedly analyzed by modern researchers, his Hrushevskyi studies works did not become the object of an independent analysis. Instead, as it will be demonstrated below, those are the key elements in the controversy with the author of «The History of Ukraine-Rus» which constructed the historical ideology of the part of Polish nation represented by F. Ravita-Gavronsky.

Research analysis. Hrushevskyi studies elements of the historical writing by F. Ravita-Gavronsky were investigated in the monographic studios of E. Koko (Koko, 2006) as well as in works of V. Telvak (Тельвак, 2008: 82, 123-125). However, as an independent problem, the Hrushevskyi studies elements in the works of F. Ravita-Gavronsky have not been studied yet. This fact determines the relevance of our research.

The purpose of the article is to clarify the specifics of the Hrushevskyi studies discourse of F. Ravita-Gavronsky.

Presenting main ideas. The first investigations of the Polish historian works concerning the research of his younger Ukrainian colleague date back to the end of the nineteenth century, when M. Hrushevskyi manifested himself as a supporter of the anti-Norman theory, which in the second half of the nineteenth century was actively developed by Naddnipryanshchyna intellectuals including his teacher V. Antonovich. Actually, F. Ravita-Gavronsky regards M. Hrushevskyi as a follower and disciple of Kyiv school in his work «Essay on the state-social structure of Russia in the eleventh and twelfth centuries». Noting the Renaissance of the 
anti-Norman theory, the Polish researcher on the pages of his book points out that the most persuasive arguments in favor of this theory were provided by V. Antonovych and M. Hrushevskyi. According to the critic, the latter, in his monograph on the Principality of Kyiv at inauguration lecture at the University of Lviv, argued that the Slavic state existed long before the invasion of the Vikings. Those were Vikings that changed the character of state to the military one. This point also became the object of emotional criticism of F. Ravita-Gavronsky, who blamed the Ukrainian colleague for being biased and willing to promote at all costs the thesis of the existence of the Principality of Kyiv before Vikings (Rawita-Gawrocski, 1896: 2-8).

F. Ravita-Gavronsky's critical reaction was not left without the answer of the Lviv professor. The mentioned book was marked on the pages of the department of scientific chronicles «Notes of SSS». Criticizing the Normanist sympathies of the Polish belletristist (as he was called by M. Hrushevskyi), the scholar noted the weakness of the author's professional competence, since in the criticized work there was not even a mentioning of the loud scientific discussions taking place in contemporary science around the problem of the influence of the Norman factor on socio-political processes in Eastern Europe. The reviewer also noted the methodological weakness of the work («methodological oscillation») and numerous factual misunderstandings, which were in abundance. In the end, refusing to admit even the elementary professionalism of the book, M. Hrushevskyi stated that «the work makes an impression of careless and pretentiously made amateurish work, a real» attack «on Rus historiography, which does not bring a special honor to either the author's name or Polish historiography, which somehow very seriously lacks a more solid acquaintance with the history of Rus» (Грушевський, 2004: 523).

Interestingly, the acute tone of M. Hrushevskyi's review was rather painfully perceived by F. Ravita-Gavronsky. In his memoirs, without mentioning the name of a Ukrainian scientist, he justified that scientific critique was too strict and did not understand the author's idea. After all, he wrote a book on socio-political relations in the Old Rus state only as «the introduction to a distant future», that is, the history of the Ukrainian Cossack (RawitaGawrocski, 2012: 54).

The intense violent scientific-organizational and socio-political activity deployed by M. Hrushevskyi at the turn of the nineteenth and twentieth centuries, attracted attention of representatives of various circles of the Polish intelligentsia, who perceived him as a threat to their dominant position in Eastern Galicia. Since then, the acuteness of perception of all aspects of Lviv professor's activity has increased significantly. The author of the «History of Ukraine-Rus» received the greatest critic from Polish publicists. In this case, the most prominent role was played by F. Ravita-Gavronsky. In his reports on the pages of numerous Polish periodicals, he emphasized the danger of deployed by M. Hrushevskyi and his colleagues activity on the suburbs of the lands. The Polish publicist was especially concerned about the events of the Lviv professor in constructing Ukrainian modern historical memory, in which the century of being under Polish rule was interpreted as a precious time lost for the Ukrainian nation to advance. From the pages of his articles, he seemed to be threatened by the «fantastic Ukraine-Rus, fabricated history by Hrushevskyi» (Rawita-Gawrocski, 2012: 96).

In order to systematically contrast the historical ideology of the Ukrainian scientist with his own historiosophical views, F. Ravita-Gavronsky founded the magazine «Ruњ» in 1911, devoted, as noted in the subtitles, to «History and Culture of Ukraine, Podolia, Volhyn and Red Rus». The fact that the critical point of the new journal was directed against the expanding M. Hrushevskyi's modern Ukrainian historical ideology was mentioned by the Polish 
writer himself in his memoirs. «The idea of the need to publish such a quarterly [«this» is the magazine «Ruњ» - aut.] has been designed in my dreams long ago» he points out: «The impetus for this was simply the need to defend our history from slander and falsehood, which was thrown by unbridled Rus historians stamped by Mykhailo Hrushevskyi, a professor at Lviv University» (Rawita-Gawrocski, 2012: 130). The content of the five issues of the magazine published in print was aimed at combating the historical visions of the author of «History of Ukraine-Rus» and representatives of his scientific school.

At the beginning of the twentieth century M. Hrushevskyi began a comprehensive study of the history of the Ukrainian Cossacks, which became the favorite area of interests of F. Ravita-Gavronsky. Having devoted a lot of historical and journalistic works to the events of the Ukrainian Cossack Revolution, the Polish researcher, of course, could not stay silent towards the work of the most authoritative specialist. Especially at the Cossack studies of Ukrainian researcher F. Ravita-Gavronsky focused his attention in his extensive article «Professor Hrushevskyi and his «History of Ukraine-Rus». Although in this work the main focus of attention is concentrated on volumes devoted to the Cossack times, the author often refers to other parts of «History...» to confirm his conclusions (Rawita-Gawrocski, 1911).

In an ironic tone peculiar of all his journalism, the researcher displays an interpretation of M. Hrushevskyi's ideas of origins and genesis of the Cossacks, as well as its role in the history of the Ukrainian nation. He ultimately admits the diligence and erudition of his Ukrainian colleague. Publicist also writes about a viable factual basis of work and a well-established chronology of events. This peculiar «backbone» of the work of the critic the author offers to leave, and all the rest, that is, the author's interpretation of the events, facts and phenomena of the history of the Cossacks, unequivocally discarded as things tendentious, unscientific, excessively subjective, caused by the «nationalist position of the author».

Disposing the past of the Cossack from the negative side and showing its exclusively devastating influence on the society of the Commonwealth (without distinction of nationality and religion), the reviewer argues that in the work of M. Hrushevskyi «the historical logic is obscured by today's political thought, the desire to turn ordinary robbers into national and ideological heroes of the twentieth century». As a result of such a bias, according to the critic, the history of the Cossack in the work of M. Hrushevskyi appears as «the only excuse to blame Poland»; and «packs of robbers» turn into «noble knights» who saw the purpose of their life in protecting the Ukrainian population. According to F. Ravita-Gavronsky, the reason for such a «distortion» of the historical past is the «pupil's» methodology of the author, consisting, on the one hand, in the bias against the arguments of the opponents, on the other - in the absence of a logical connection between the derivative facts and the proclaimed conclusion, an attempt to falsify the fact-finding under the pre-formulated thesis and the constructed structure. The reviewer was not satisfied by the linguistic side too, the reason: the «young» Ukrainian language, the inexorability of its conceptual apparatus, which made the style of «History» «excessively difficult to read».

F. Ravita-Gavronsky criticized the most the terminology of M. Hrushevskyi: he considers it absolutely unjustified to use the term «Ukraine-Rus». Especially inappropriate it seems in the context of East European history of the early Middle Ages. It is noteworthy that, when explaining the motivation of a Ukrainian scientist in constructing a new historical terminology, F. Ravita-Gavronsky emphasizes on his political «state» bias which led to logical «historical» and «territorial» claims to Russia, Austria-Hungary and Poland. Therefore, the 
Polish researcher emphasizes on the artificiality of M. Hrushevskyi's reconstructed Ukrainian historical model in such a far-reaching retrospective and within such a widely-defined ethnographic territory.

The latter thesis F. Ravita-Gavronsky was actively developed in his numerous journalistic writings, emphasizing the weakness and underdevelopment of the cultural and national life of Ukrainians (he called the latter Rusyns), who are not ready yet for active social and political life, since they do not fully realize their own needs. «Their misfortune is», he pointed out outwardly, «that the Rusyns want more than their mental, cultural and material strengths may cover, that their aspirations never correspond to reality and its boundaries, that the restlessness of their primitive nature - the ethnic character - brings them more harm than anything else taken and described by Hrushevskyi and his followers» (Rawita-Gawrocski, 1912: 575). As a result of this weakness, F. Ravita-Gavronsky claims, Ukrainians uncritically perceive the political ideas of Ukrainian activists and, above all, of M. Hrushevskyi, «an ardent socialist».

In his writings, the Polish publicist does not spare space for harsh characteristics of the Ukrainian elite, depicting its representatives as immoral and selfish intriguers who are completely indifferent to the fate of their own people. At the same time, the researcher is not limited only by his time, but boldly reaches the depths of centuries. Thus, characterizing the activities of the Ukrainian hetmans after Khmelnytsky, he notes: «We have investigated only half a century, but how much it involves arbitrariness, betrayal, and murders. This was not done for the sake of the goodness of the people, not for the sake of state secrecy, not for the sake of lost rights, but only for the sake disturbances, with a blindness towards any other goal but their own» (Rawita-Gawrocski, 1912: 568). The political traditions of hetmans, as F. Ravita-Gavronsky states, were continued by Ukrainian activists from the beginning of the twentieth century (Rawita-Gawrocski, 1909: 18, 21). This was especially dangerous on the eve of the inevitable conflict on the European arena, when Ukrainians led by such «adventurist» leaders will surely speak out, as he pointed out, against the hegemony of the Polish in Eastern Galicia. It should be noted that the negative evaluations that F. Ravita-Gavronsky used to criticize M. Hrushevskyi's ideas were disseminated by Polish scholars to the whole group of Ukrainian intellectuals - in their work he saw a threat to the future of Poland.

The Polish researcher also wrote critical works to the Cossack studies heritage of M. Hrushevskyi. On their pages, which should be emphasized, he always paid tribute to the efforts of his Ukrainian colleague to enrich the Source study of this prominent period of the Ukrainian past. At the same time, F. Ravita-Gavronsky, for the most part, repeated the above-mentioned criticism concerning «History of Ukraine-Rus» and the personality of its author. For example, in his work at the eve of the First World War, «The Territory, the Population and the Creation of the Cossacks», the publicist once again subjected to a crushing critique of the idealization of national movements by «historians from the school of Antonovich-Hrushevskyi» (Rawita-Gawrocski, 1914: 68).

However, in this case, M. Hrushevskyi did not stay silent, having criticized a collection of sources for the history of the Cossacks, prepared by a Polish researcher on the pages of the Kievan «Ukraine» edited by the historian. First of all, the columnist pointed out the informational value of the reprinted and for the first time introduced to the scientific circulation sources. Alongside this, the critic has demonstrated on numerous examples the Source study and archaeological incompetence of F. Ravita-Gavronsky, who published his texts in a «sloppy manner», with an enormous amount of errors that significantly distort the actual content of historical documents (Грушевський, 2014). 
At the eve of the First World War, the tensions in the Ukrainian and Polish societies increased markedly due to the approaching crisis of a pan-European scale. At this time, F. Ravita-Gavronsky significantly exacerbated his journalistic talent in relation to the Ukrainian problem and personally M. Hrushevskyi, often falling into a frank vulgarity of tone. Thus, in the extensive article «The Rus Question Regarding Austria and Russia», he introduced his opponent to the readers as «the son of a priest from Helm», although he was well acquainted with the biography of the Lviv professor (Rawita-Gawrocski, 1912: 569). This, apparently, was a reflection of Polish gentry towards people from the Orthodox clergy environment.

The First World War convinced F. Ravita-Gavronsky in the rightness of his fears. Brought up on the writings of M. Hrushevskyi, a new generation of Ukrainians with arms in hands took up the implementation of the slogans of state independence. The author of «The History of Ukraine-Rus», as it was once anticipated by his Polish opponent, was at the head of the first Ukrainian government. The sad experience of the Polish-Ukrainian confrontation has further exacerbated the critique of F. Ravita-Gavronsky in relation to Ukrainian political figures and their, as he repeatedly pointed out, precursors of the middle of the XVII century. Thus, in the book «Genesis and the development of the idea of the Cossacks and Cossackhood in the XVI century», the researcher with a new force was criticizing the interpretation of M. Hrushevskyi and his followers of key events in the history of Ukrainian during early modern times. Blaming the author of «The History of Ukraine-Russia» for an idealization and considerable subjectivity in assessments of historical phenomena, the Polish journalist emphasized that «representatives of the Kyiv school» transformed the history of the Cossacks into «the history of national martyrdom» (Rawita-Gawrocski, 1924: 150). At the same time, F. Ravita-Gavronsky continued to pay tribute to the Source study achievements of his Ukrainian colleague at the field of Cossack archaeography.

Alongside with the controversy around the events of the Ukrainian Cossack Revolution, F. Ravita-Gavronsky continued to criticize the underlying elements of M. Hrushevskyi's constructed national historical ideology. Like other Polish publicists, he further argued with the terminology of his Ukrainian counterpart, particularly strongly denouncing the unlawfulness of the use of the «Ukraine» toponym in the context of the Eastern European Middle Ages. In one of his later works, F. Ravita-Gavronsky once again emphasized on the artificiality and inappropriateness of using M. Hrushevskyi's toponym «Ukraine» instead of historically justified and reasoned, in his opinion, «Rus», explaining the historiographical motivation of his Ukrainian colleague exclusively by «chauvinistic persuasions»: «From his [M. Hrushevskyi] side it was», as the Polish scholar remarked, «a kind of licentia poetica against history, truth and logic, which had no support other than political views themselves» (Rawita-Gawrocski, 1922: 15). He once again lists the controversial M. Hrushevskyi's ideas, the most important of which is the vision of popular movements of the XVI - XVIII centuries, as a national liberation factor, and thus, the publicist conducts an emotional polemic with them.

Apart from this, F. Ravita-Gavronsky regards the public-political activity of M. Hrushevskyi as a field for the realization of his historiographical hypotheses. He sees it as an attempt of the researcher to create, with Berlin's support, an artificial (in its expression - «bookish») national community of the Ukrainian population of Russia and Austria-Hungary - the demonstration of an outright hostility towards the idea of restoration of Polish statehood within the ancient Commonwealth, the propaganda of Polish-Ukrainian hatred in Eastern Galicia (Rawita-Gawrocski, 1922: 17-19).

Estimating from the height of past years the diverse activities of M. Hrushevskyi in Lviv, F. Ravita-Gavronsky criticized the consequences quite strictly. Describing the Badeni- 
Romanchuk agreement as an unfortunate political combination that did not bring the Polish nation the desired inter-ethnic appeasement in Eastern Galicia, the publicist listed among the other failures the appointment of M. Hrushevskyi at the post of the head of Department of History at Lviv University. By directly demonizing the influences of his long-time antagonist on contemporary Ukrainians, he categorically declared himself: «Peaceful before Galician society [M. Hrushevskyi] plunged into the path of hatred against the Polish people, following an example of Russian historians by fomenting historic agendas and making them a model for the present» (Koko, 2006: 138).

Conclusions. Summing up the Hrushevskyi studies of F. Ravita-Gavronsky, we shall point out its features, which were typical of all Polish journalism concerning the Ukrainian question. First of all, it is irreconcilable in the perception of the modern Ukrainian historical ideology that was designed by M. Hrushevskyi and his associates through the «cutting off» Polish and Russian distortions of the Ukrainian historical narrative. As a consequence of this process, as is was predicted by the Polish researcher, there was the emergence of a new national outlook, the bearers of which questioned the domination of the Polish nation in the ethnic Ukrainian lands. Honestly seeing M. Hrushevskyi as an ideologue of Ukrainian national life rather than a cabinet scientist, F. Ravita-Gavronsky regarded through this prism his academic works. However, this level of professionalism of an amateur Ukrainian studies scientist was obviously not enough, and we do not see an argumentative polemic with the historiographical hypotheses of the author of «The History of Ukraine-Rus», but rather an outright profanation. Therefore, it is not surprising that the Polish scientists themselves did not support the controversial zeal of F. Ravita-Gavronsky, but appreciated much more the creative efforts of his opponent. The journalist himself witnessed the sad consequences of the tactics chosen by him and the majority of the Polish politician regarding the Ukrainian movement, to be more precise, the refusal to establish a dialogue and the lack of desire to understand the another side led to a bloody Polish-Ukrainian war and the further radicalization of interethnic relations in the interwar period. But even this did not push a talented publicist not only to try to reconsider, but at least to correct his attitude towards the nation, which he deliberately denied to call by its own name during his whole life.

\section{BIBLIOGRAPHY}

Грушевський, 2004 - Грушевський М. Нові розвідки з історії давньої Руси // Грушевський М.С. Твори: У 50 т. / Редкол.: П. Сохань, Я. Дашкевич, І. Гирич та ін.; Голов. ред. П. Сохань. Львів: Світ, 2004. Т. 6: Серія «Історичні студії та розвідки (1895 - 1900)». С. 512-533.

Грушевський, 2014 - Грушевський М.: Sprawy i rzeczy ukraińskie. Materyały do dziejów kozaczyzny i hajdamaczyzny, wydał Fr. Rawita-Gawrońsky. Lwów, 1914, ст. 14 // Україна. 1914. Кн. 3. С. 94-95.

Тельвак, 2008 - Тельвак В. Творча спадщина Михайла Грушевського в оцінках сучасників (кінець XIX - 30-ті роки XX століття). Київ-Дрогобич, 2008. 494 с.

Koko, 2006 - Koko E. Franciszek Rawita-Gawroński (1846 - 1930) wobec Ukrainy i jej przeszłości. Gdańsk: Wydawnictwo Uniwersytetu Gdańskiego, 2006. 274 s.

Rawita-Gawroński, 1924 - Rawita-Gawroński Fr. Geneza i rozwój idei Kozactwa i Kozaczyzny w XVI wieku. Warszawa-Kraków, 1924. 150 s.

Rawita-Gawroński, 1922 - Rawita-Gawroński Fr. Kozaczyzna Ukrainna w Rzeczypospolitej Polskiej do końca XVIII-go wieku. Zarys polityczno-historyczny. Warszawa-Kraków-Lublin-ŁódżPoznań-Wilno-Zakopane, 1922. $238 \mathrm{~s}$.

Rawita-Gawroński, 1912 - Rawita-Gawroński Fr. Kwestya ruska wobec Austryi i Rosyi // Świat Słowiański. Kraków, 1912. Rocznik VIII. Sierpień-Wrzesień. S. 557-578. 
Rawita-Gawroński, 2012 - Rawita-Gawroński Fr. Ludzie i czasy mego wieku. Wspomnienia, wypadki, zapiski (1892 - 1914). Gdańsk, 2012. 265 s.

Rawita-Gawroński, 1914 - Rawita-Gawroński Fr. Obszar, zaludnienie i tworzenie się Kozaczyzny. Kraków, 1914. $70 \mathrm{~s}$.

Rawita-Gawroński, 1909 - Rawita-Gawroński Fr. Oderwanie Chełmszczyzny i Rusini. Lwów, 1909. $24 \mathrm{~s}$.

Rawita-Gawroński, 1911 - Rawita-Gawroński Fr. Profesor Hruszewskij i jego Historia UkrainyRusi // Świat Słowiański. Kraków, 1911. Rocznik VII. Maj. S. 337-356.

Rawita-Gawroński, 1896 - Rawita-Gawroński Fr. Ustrój państwowo-społeczny Rusi w XI i XII w. W zarysie. Lwów, 1896. 222 s.

\section{REFERENCES}

Hrushevskyi, 2004 - Hrushevskyi M. Novi rozvidky z istorii davnoi Rusy [New Research on the History of Ancient Rus] // Hrushevskyi M. S. Tvory: U 50 t. Lviv: Svit, 2004. T. 6: Seriia «Istorychni studii ta rozvidky (1895 - 1900)» [Hrushevsky M. S. Works: In 50 Vol. - Lviv: World, 2004. - Vol. 6: Series «Historical Studies and Investigations (1895 - 1900)»]. S. 512-533. [in Ukrainian]

Hrushevskyi,, 2014 - Hrushevskyi M.: Sprawy i rzeczy ukraińskie. Materyały do dziejów kozaczyzny i hajdamaczyzny, wydał Fr. Rawita-Gawrońsky. Lwów, 1914, ст. 14 [Cases and Cossacks' History and Haidamachyna, published by Fr. Rawita-Gawrońsky. Lwów, 1914, p. 14] // Ukraine. 1914. Book 3. S. 94-95. [in Ukrainian]

Telvak, 2008 - Telvak V. Tvorcha spadshchyna Mykhaila Hrushevskoho v otsinkakh suchasnykiv (kinets XIX - 30-ti roky XX stolittia) [The creative heritage of Mykhailo Hrushevsky in the evaluation of contemporaries (the end of the 19th and the 30th years of the twentieth century)]. Kyiv-Drohobych, 2008. 494 s. [in Ukrainian]

Koko, 2006 - Koko E. Franciszek Rawita-Gawroński (1846 - 1930) wobec Ukrainy i jej przeszłości [Franciszek Rawita-Gawroński (1846 - 193 0) about Ukraine and its past]. Gdańsk: Wydawnictwo Uniwersytetu Gdańskiego, 2006. 274 s. [in Polish]

Rawita-Gawroński, 1924 - Rawita-Gawroński Fr. Geneza i rozwój idei Kozactwa i Kozaczyzny w XVI wieku [Genesis and the development of the idea of the Cossacks and the Cossackhood in the XVI century]. Warszawa-Kraków, 1924. 150 s. [in Polish]

Rawita-Gawroński, 1922 - Rawita-Gawroński Fr. Kozaczyzna Ukrainna w Rzeczypospolitej Polskiej do końca XVIII-go wieku. Zarys polityczno-historyczny [Ukrainka Cossack in the Polish Republic to the end of the XVIII-th century., Political-historical essay]. Warszawa-Kraków-LublinŁódż-Poznań-Wilno-Zakopane, 1922. 238 s. [in Polish]

Rawita-Gawroński, 1912 - Rawita-Gawroński Fr. Kwestya ruska wobec Austryi i Rosyi [Rusyn Question and Austria and Russia]// Slavic World. Kraków, 1912. Vol. VIII. Sierpień-Wrzesień. S. 557-578. [in Polish]

Rawita-Gawroński, 2012 - Rawita-Gawroński Fr. Ludzie i czasy mego wieku. Wspomnienia, wypadki, zapiski (1892 - 1914) [People and times of my age. Memoirs, events, notes (1892-1914)]. Gdańsk, 2012. 265 s. [in Polish]

Rawita-Gawroński, 1914 - Rawita-Gawroński Fr. Obszar, zaludnienie i tworzenie się Kozaczyzny [Territory, Population and Creation of the Cossackhood]. Kraków, 1914. 70 s. [in Polish]

Rawita-Gawroński, 1909 - Rawita-Gawroński Fr. Oderwanie Chełmszczyzny i Rusini [Deportation of the Kholmshchyna and Rusyns]. Lwów, 1909. 24 s. [in Polish]

Rawita-Gawroński, 1911 - Rawita-Gawroński Fr. Profesor Hruszewskij i jego Historia UkrainyRusi [Professor Hrushevsky and his History of Ukraine-Rus] // Slavic World. Kraków, 1911. Vol. VII. Maj. S. 337-356. [in Polish]

Rawita-Gawroński, 1896 - Rawita-Gawroński Fr. Ustrój państwowo-społeczny Rusi w XI i XII w. W zarysie. [Essay of the state-social system of Russia XI and XII centuries. In outline] Lwów, 1896. 222 s. [in Polish]

Стаття надійшла до редакиії 10.04.2018 р. 